Revue Française de Civilisation Britannique

French Journal of British Studies

XII-2 | 2003

La situation et les politiques de l'emploi en France et en Grande-Bretagne, 1990-2000

\title{
Worlds Apart? Unemployment Policy and Politics in Britain and France
}

Deux mondes à part? Politique et politiques de l'emploi en Grande-Bretagne et en France

Daniel Clegg and Jochen Clasen

\section{OpenEdition \\ Journals}

Electronic version

URL: http://journals.openedition.org/rfcb/3164

DOI: $10.4000 /$ rfcb.3164

ISSN: 2429-4373

Publisher

CRECIB - Centre de recherche et d'études en civilisation britannique

Printed version

Date of publication: 1 April 2003

ISBN: 2-911580-16-8

ISSN: 0248-9015

This text was automatically generated on 31 May 2019

\section{c) $(9)$}

Revue française de civilisation britannique est mis à disposition selon les termes de la licence Creative Commons Attribution - Pas d'Utilisation Commerciale - Pas de Modification 4.0 International. 


\section{Worlds Apart? Unemployment Policy and Politics in Britain and France}

Deux mondes à part? Politique et politiques de l'emploi en Grande-Bretagne et en France

Daniel Clegg and Jochen Clasen

1 British and French unemployment policy in the 1990s is often seen as being 'worlds apart', a product of diametrically and unambiguously opposed reactions to the changed international economic environment since the mid-1970s. As we describe in the first section of this paper, their different approaches to unemployment policy are seen as resting on contrasting patterns of labour market reform, themselves a reflection of the different values which determine political choices in each state. Our second section shows firstly how some trends in unemployment and employment in the two countries over the 1990 s appear to lend credence to this notion of 'two worlds'. However, a more complicated picture emerges once we get behind the headline figures, and furthermore has its corollary in the counter-intuitive trends which emerge from a more detailed examination of employment regulation. When we look in turn more closely at unemployment policy, in our third section, we see that it too manifests less the antithetical trends that would confirm a politics based on opposing values, than subtle differences which appear to owe much to the diverse political consequences of varying institutional legacies.

\section{Britain versus France: a Tale of Two Regulatory Trinities}

2 The conventional opposition between British and French responses to slower growth and rising unemployment can be presented in terms of their different combinations of three features of public policy and politics in the interlocking domains of labour market 
adjustment and unemployment protection. To Britain's junction of deregulation-workfareindividualism is contrasted France's triad of regulation-social treatment of unemploymentsolidarity. The values on the three variables - labour market regulation, unemployment policy and polity values - are seen to coalesce and complement each other in stable 'regulatory trinities'.

3 A recent overview of labour market policy in Europe suggested that Britain is the closest approximation to complete deregulation in Western Europe, while France is the Continent's best example of regulatory stasis. ${ }^{1}$ Where for France we can speak of the 'deregulation that never existed', ${ }^{2}$ and even note the introduction of new 'rigidities', controversy in Britain tends to centre on whether the changes which have intervened since the early 1980s should be seen as a 'river crossing' or a 'cold bath's, but not on the reality or direction of changes. Recent attempts to construct synthetic indicators of levels of labour market regulation would indeed suggest that Britain today has a profile of labour market regulation which is much closer to the United States than it is to France or Germany. ${ }^{4}$

4 These differences are reproduced in political discourse on the economy. Flexibility is a notoriously unpopular idea among French policy makers who, if they venture onto the dangerous territory of labour market deregulation, have long limited themselves to timid calls for souplesse. At the Stockholm European Council of March 2001, Tony Blair's standard plea for greater flexibility in the interests of employment growth were countered by a co-ordinated response from France's cohabiting Prime Minister Jospin and President Chirac who, with a single voice which belied any underlying ideological affiliations, insisted on the need for new employment in Europe to be 'of quality' and 'correctly remunerated'.

5 The respective areas of unemployment compensation are closely coupled to this picture of the contrasting evolution of labour market regulation. In this perspective, the diverging structure of the labour market has bequeathed different 'regulatory dilemmas' to which classical policies for unemployment protection have responded. In Britain, the main regulatory dilemma has been the limited attractiveness of new employment opportunities which, in the more flexible labour market, are often low-paying and insecure. There have therefore been pressures to increase the financial incentives related to employment, which has been achieved most crudely by simply scaling-back entitlement to unemployment protection. Earnings-related supplements to unemployment benefits were an early victim of Thatcherism, and the old basic unemployment benefit was subject to repeated cuts and more restrictive entitlement conditions in the 1980s and 1990s. ${ }^{5}$ The introduction of the Job Seekers Allowance (JSA) in 1996 can be seen as the end-point of this process of retrenchment motivated principally by the twin aims of containing social security spending and enhancing job search requirements. Propping-up the peripheral labour market also passed by shifting a large part of the burden of existing social expenditure towards means-tested, in-work benefits and tax-based wage subsidies (Family Credit, then Working Family Tax Credit), which act to subsidise low incomes for working individuals and families. This social security strategy has been called 'market workfare'. ${ }^{6}$ It has been accompanied by the redeployment of employment services and training initiatives, which have followed their own "workfarist progression" towards enforcing labour market discipline through a raft of compulsory job-search, training and employment preparation initiatives. ${ }^{7}$ 
The very differently connoted notion at the centre of French debates has been the 'social treatment' of unemployment (le traitement social du chômage). This appears as explicit recognition of the fact that the main regulatory dilemma posed by France's resistance to greater wage flexibility in the labour market will be the existence of important levels of unemployment, which it is necessary to 'treat', socially and humanely. One important instrument for this has been the French system of straightforward unemployment compensation, which Jacques Chirac, then Prime Minister, was already lauding in 1974 as the 'best in the world'. This declaration followed the passage of a reform which had established a special $90 \%$ rate of unemployment benefit, the allocation supplémentaire d'attente (ASA), for those made redundant under particular conditions. While the ASA did not survive the worsening of the economic climate in the late 1970s, benefits for the French unemployed do seem to have remained considerably more generous than those of their British counterparts, in terms of both their level and their duration. In 1997, the median replacement rate of unemployment benefits in France was $56 \%$ of previous income, while the equivalent figure for the flat-rate British benefits can be calculated at around $25 \%$. While benefits under the JSA regime are paid without a means-test for a maximum of 6 months in Britain, the duration of benefit entitlement can be as high as 5 years in France, notably for the older unemployed. ${ }^{8}$ This sees unemployment benefit provision overlapping in important ways with early retirement measures, another important mechanism in France's strategy of social treatment and even more clear evidence of the strategy of removing less productive workers from the labour force. Early retirement measures consistently took up $15-25 \%$ of labour market policy expenditure in the 1980s. ${ }^{9}$

The third pillar of the regulatory trinity is supplied by the different values which are held to underpin labour market and unemployment policy in Britain and France. These values influence voters' responses to social phenomena, cementing the very understanding of regulatory dilemmas, and thus determining the legitimacy of policy initiatives in the domain of labour market regulation and unemployment.

In Britain, it is a classically liberal individualism which is seen to dominate policy discussions of labour market phenomena. Individualism legitimates increased competitiveness, in the labour market as elsewhere, and accords badly with union demands for either collectively negotiated or legislative safeguards. Coupled with traumatic memories of the industrial disputes of the 1970s, individualism thus legitimised the Thatcher administration's labelling of the trade union movement as 'the enemy within', and facilitated the dismantling of the union's workplace prerogatives, and the overriding of their demands and preferences in national policy. ${ }^{10}$

By contrast, in France, the very low formal strength of the trade union movement (whose rates of membership are the lowest in Europe) seems to be compensated by a widespread public sympathy, or solidarity, with their demands. A recent study of public attitudes towards unions concluded that, in spite of its weaknesses, internal divisions and petty rivalries, the French labour movement enjoys across society a 'real and in some dimensions consensual legitimacy. ${ }^{11}$ Evidence can be found in the broad public support for the massive strike in the winter of 1995 , despite the importance of essentially sectional interests in provoking the mobilisation.

10 Contrasting polity values can also be seen to have an influence on social protection orientations, and thus on the shape of unemployment policy. Van Oorschot has found some evidence that suspicion as to the 'deservingness' of social transfer beneficiaries 
'seems to be stronger in the Anglo-Saxon individual-oriented countries like the UK, US and Australia than in collectively-oriented continental European countries'. ${ }^{12}$ The British and French cases appear to confirm this, and attest to the policy implications. For King, ${ }^{13}$ the same classically liberal, individualist values which underpinned the punitive deterrence approach of the 1834 British Poor Law resurfaced to facilitate the scaling-back of unemployment protection in Britain in the 1980s and 1990s. Somewhat confusingly, they can also be considered to have underpinned policies which themselves appear inherently illiberal, such as workfare. ${ }^{14}$ The current Labour government's 'New Deal' programme for the unemployed, with its language of 'balancing rights with responsibilities', can be seen as further evidence of the effectiveness of individualist themes in propping up labour market deregulation in Britain.

In France, assistance to the needy was on the contrary identified by the revolutionaries as a 'sacred debt', and the idea that the state owes assistance to the individual is said to underpin the French Republican concepts of fraternity and (national) solidarity. It is argued that in the presence of such solidarist reflexes in the electorate, attacks on social provision have not been able to provide a pretext for the introduction of greater labour market flexibility. ${ }^{15}$ This could be seen to explain, for example, why the Jospin government fought so long and hard against the recent proposals by the main French employers' association to attach unemployment benefit receipt to 'return to work' measures through the Plan d'Aide au Retour à l'Emploi, (PARE), even after it had received the support of three of the five principal union confederations.

It is thus suggested that the nexus of social benefit provision and labour market regulation tend in Britain and France ever more towards the polarised roles assigned to them by Leibfried, ${ }^{16}$ respectively 'work-enforcement' and 'first-resort compensation'. The end product should ultimately be the transformation of a common problem of low growth and rising unemployment into two distinct 'post golden-age' regulatory profiles, based on low rates of labour market exclusion but high rates of 'active poverty' in the first case, and a permanently large pool of long-term unemployed and early retirees in the second.

\section{Worlds Apart? French and British Labour Markets in the 1990s}

Certain labour market trends in Britain and France over the 1990s would seem to confirm this portrayal of 'two worlds', increasingly far apart. As far as the trajectory of main unemployment indicators in the 1990s is concerned, the UK and France have moved further apart rather than become more similar over time. This is particularly true for overall unemployment, unemployment amongst women and younger people (see table 1). In addition, long-term unemployment is about twice as high in France as it is in the UK, with no real decline between 1991 and 2000 (4\% of the labour force) compared with significant decline in the UK (to $1.5 \%$ ). ${ }^{17}$

Employment rates have remained very different. Britain has one of the highest rates of employment in the EU, climbing (by $2 \%$ ) to $71 \%$ by the end of the 1990 s. ${ }^{18}$ The French rate rose by about the same margin, which means that the difference between the two countries remained about $10 \%$ points throughout the past decade. About a quarter of the total British workforce works part-time compared to $17 \%$ in France. Much of this part time is performed by women. In France about a third of all women work part-time and in 
the UK about $45 \%$. With Spain and Denmark, the UK has relatively high rates of short job tenures (less than one year; less than two years) compared with other EU countries. By contrast, job tenures in France are above the EU average (EC, 2001). ${ }^{19}$

Table 1. Unemployment rates: female unemployment and youth unemployment (\%)

\begin{tabular}{|l|l|l|l|l|l|l|l|l|l|l|l|}
\hline & 11989 & 11990 & 11991 & 11992 & 11993 & 11994 & 11995 & 11996 & 11997 & 11998 & 11999 \\
\hline u F & 9.4 & 9.9 & 9.5 & 10.4 & 11.7 & 12.3 & 11.7 & 12.4 & 12.3 & 11.8 & 11.3 \\
\hline u UK & 7.3 & 7.0 & 8.8 & 10.0 & 10.5 & 9.6 & 8.7 & 8.2 & 7.0 & 6.3 & 6.1 \\
\hline FF & 12.4 & 11.9 & 12.1 & 13.0 & 13.8 & 14.5 & 14.0 & 14.5 & 14.4 & 13.9 & 13.3 \\
\hline F UK & 7.1 & 6.6 & 7.5 & 7.7 & 8.1 & 7.5 & 7.0 & 6.5 & 6.0 & 5.5 & 5.3 \\
\hline Y F & 20.2 & 19.5 & 21.3 & 23.3 & 27.3 & 29.2 & 27.5 & 29.1 & 29.2 & 26.5 & 24.2 \\
\hline Y UK & 10.4 & 10.8 & 14.4 & 16.7 & 18.1 & 17.0 & 15.9 & 15.5 & 14.2 & 13.6 & 13.0 \\
\hline
\end{tabular}

Source: Eurostat Yearbook 2001

15 A similar difference marks each country's activity rates, which, for the population aged 15 to 64 , are higher in the UK (75\%) than in France (68\%). These differences become even more stark once we concentrate our attention on groups at either end of the working life. Both younger people and particularly older people in Britain have higher activity rates than their French counterparts. This is particularly true for men aged 50 to 64 , who have an activity rate of $73 \%$ in the UK but only $57 \%$ in France, an indicator of the effects of the early retirement policies pursued in the latter.

While all the above would tend to confirm the images of 'two worlds', in other respects the evidence for such outcomes is less convincing. There are some crucial variables which suggest that the differences between Britain and France are not as categorical as first assumed, that there are functional equivalents and that trends of convergence can be observed. Furthermore, in some respects France seems to have moved further ahead in terms of creating labour market flexibility than Britain.

Overall activity rates in Britain and France are actually more similar today than at the start of the 1990s, particularly for prime age (25-49) men and women. ${ }^{20}$ The reasons for this convergence were growing female activity rates in both countries (rising to $63 \%$ in France and $68 \%$ in the UK by 1999), and a simultaneous decline of the male activity rate in the UK (from $86 \%$ to $82 \%$ ). Even among the group where differences remain most significant, men aged 50 to 64 , there has been some convergence, with the $3 \%$ fall in activity rates, from $76 \%$ to $73 \%$, in the UK between 1989 and 1999 in reality having no equivalent in France, where the (low) activity rate has been stable, at $57 \%$, for the last decade. One implication of such figures is that the increasing gap between the French and British unemployment rates in the 1990s could be, at least as far as men of prime working age are concerned, partly due to a move from unemployment into inactivity rather than employment in Britain. This has been shown by Ganßmann, ${ }^{21}$ who indicates that the decline of measured unemployment as a share of non-employment of men aged 25-54 has been much more rapid in the UK than in France. 
In employment trends, too, there is some evidence of convergence. Rates of female parttime employment remain different, as we saw above, but are much less so today than at the end of the 1980s. The proportion of British women working part-time hardly changed during the entire 1990s, while the rate of French women increased by almost a third in the first half of the decade. Levels of voluntary part-time employment are also higher in Britain than in France. ${ }^{22}$ More generally, many flexible forms of working are more widespread in France than in Britain, or have increased faster in the former than the latter (see table 2). In 2000, fixed-term employment had fallen back to $6 \%$ of total employment in Britain, but represented $14 \%$ in France. ${ }^{23}$

Table 2: 'Atypical employment' 1985-1996

\begin{tabular}{|l|l|l|l|l|l|l|}
\hline & \multicolumn{2}{l}{1985} & \multicolumn{2}{l}{1996} & \multicolumn{2}{l|}{ \% change 85-96 } \\
\hline & Part-time & Fixed-term & Part-time & Fixed-term & Part-time & Fixed-term \\
\hline Germany & 12.8 & 10 & 16.5 & 11.1 & +28.9 & +11 \\
\hline France & 10.9 & 4.7 & 16 & 12.6 & +46.8 & +168.1 \\
\hline UK & 21.2 & 7 & 24.6 & 7.1 & +16 & +1.4 \\
\hline USA & 18.4 & n.a. & 18.3 & 2.2 & -0.5 & n.a. \\
\hline
\end{tabular}

'Part-time' = part-time employment as a \% of all employment; 'Fixed-term' = fixed-term contracts as a $\%$ of all employment contracts. Adapted from Table 2B, p. 56 in M. LODIVICI, 'The dynamics of labour market reform in European countries', in G. ESPING-ANDERSEN \& M. REGINI (eds.) Why Deregulate Labour Markets?, Oxford: OUP, 2000.

19 While short-employment tenures remain more prevalent in Britain, in terms of perceived job security the two states are very close together. The OECD assessed a range of studies on job insecurity across countries. ${ }^{24}$ While data is not always directly comparable, the International Social Survey Programme (ISSP) indicates a high level of employment insecurity in both countries. Indeed, a composite indicator suggests that between 1992 and 1996, job insecurity in the UK and France had increased to levels which were higher than in any other European countries, and close to levels recorded in Japan and the US.

These similarities between Britain and France and counter-intuitive differences indicate that a characterisation of British and French labour markets and employment models are not very well captured by a simple opposition between 'flexibility' and 'rigidity'. Synthetic indicators of labour market regulation, for example, tend to pose as many questions as they answer. Britain has always had a much less regulated labour market than the Roman-law states of continental Europe, with their heavy, detailed labour codes. Secondly, even if we accept the validity of the comparison, much appears to turn on the selection of variables and indicators. ${ }^{25}$ Another recent study, differently constructed, shows that France can be considered a more 'net' structural reformer of the labour market than Britain. ${ }^{26}$ It is no surprise then if, as the previous section has shown, indicators such as employment tenure and feelings of job security do not always confirm simple images of flexibility or rigidity. 
21 A related point is that the indicators themselves capture a complex reality rather poorly, particularly in those states with elaborate labour codes. Global indicators of labour market regulation often refer to apparently typical labour market situations which are however far from general. The very politically controversial rules which, in France, impose heavy obligations on enterprises which have recourse to redundancies, but which apply only in enterprises of a certain size under precisely defined conditions and thus concern no more than $15 \%$ of all 'economic redundancies', are a case in point. For similar reasons, it is hazardous to make generalisations on the basis of the conditions which regulate the 'standard' labour contract, which is often taken as in some way representative of the degree of labour market regulation. In fact, the expansion of 'atypical' employment has been the manner in which flexibility has been introduced in many European states since the early- to mid-1980s. As shown above, the growth of 'atypical employment' between 1985 and 1996 was accordingly much more dramatic in France than was the case not only in Britain, but also in Germany. As the protection offered by a 'standard' or 'typical' employment relationship is relatively low in Britain, there has been less incentive for employers to have recourse to atypical employment forms. ${ }^{27}$ This observation serves to highlight a final difficulty with indicators of labour market regulation, namely that in certain contexts the introduction of 'flexibility' will be effected by more, not less, regulation.

This, it seems to us, is an important part of the French story, where the protections associated to the contrat de durée indéterminée (CDI) have been maintained or even reinforced, while at the same time labour law has developed new, derogatory employment statutes. Alongside part-time employment and regular contrats de durée déterminée a multiplicity of 'peripheral' employment forms - intérim, stages, contrats aidés have also developed, and at moments made up around $10 \%$ of all salaried employment. Apart from the lower hiring and firing costs they entail, and despite being calculated 'on the basis' of the minimum wage, many involve low levels of remuneration due to the limited number of hours worked per week. Research has shown that they are often associated with material poverty and psychological distress. ${ }^{28}$ The growth of such forms of employment has been one of the principal reasons for the emergence, in France, of significant numbers of 'working poor'. ${ }^{29}$ The recent introduction, then augmentation, of a means-tested in-work benefit, the prime pour l'emploi (PPE), was an explicit recognition of this fact in policy.

\section{A Closer Look at Unemployment Policy and Politics in Britain and France}

The PPE, with its apparent similarities to New Labour's strategy to 'make work pay', suggests that differences between (un)employment policies in Britain and France may be more complex than is suggested by the opposition between 'workfare' and 'social treatment of unemployment'. This impression is reinforced when we look at conventional unemployment benefits, where the differences are in practice less great than suggested by straightforward replacement rates. At the macro-level, the percentage of GDP spent on unemployment insurance benefits for each percentage point of unemployment was only slightly higher in 1995 in France (0.12) than in Britain (0.10), and had fallen further since 1991 in France (from 0.15) than in Britain (from 0.12). ${ }^{30}$ At the micro-level, once housing benefits and other means-tested transfers are added, some British household types with 
below-average income seem to receive the same or even a slightly higher level of income replacement than their French counterparts. ${ }^{31}$ Based on ECHP survey data from 1994 (and people who were unemployed throughout 1993), Gallie and Paugam ${ }^{32}$ also show that (including housing benefit) the gap between the UK replacement rate and nine other EU countries is smaller than some hypothetical case-based data indicate. While Gallie et al. ${ }^{33}$ showed that on the basis of the first three waves (1994-96) of the ECHP almost half of the British unemployed - considerably above the average of the 11 other EU countries covered - were poor (having less than $60 \%$ of equivalised household median income), the equivalent figure for France was for its part over one third.

Most interesting of all, however, are the respective profiles of 'active policies' in each state. If the 'two regulatory trinities' outlined above might suggest that it would be Britain which has developed an increasingly active labour market policy since the late 1980s, this is not borne out by the data on labour market policy effort. Quite the opposite. Ever since the mid-1980s UK spending on active labour market policy has been in decline, reaching $0.37 \%$ of GDP by 1998 . By comparison, France devoted $1.33 \%$ to active programmes in the same year. ${ }^{34}$ As a percentage of GDP France and the UK spent the same (0.16\%) on employment services and administration in 1998. ${ }^{35}$ However, France devoted four times as much on training and three times as much on youth measures as the UK. Even more tellingly, subsidised employment measures did not even register with the British active portfolio in 1999, while France spent more than a third of its expenditure on active measures on schemes such as job creation and wage subsidies. ${ }^{36}$

The New Deal programmes introduced by the Labour government in Britain since 1998 have not altered this picture significantly. By 1999/2000 they raised total spending on active labour market policy by merely one tenth of a percentage point of GDP. Since this remained well below expenditure levels earlier in the decade, ${ }^{37}$ the New Deal has done little to reverse the trend in declining expenditure on active measures since the 1980 s. The New Deal does not, in short, represent a radically different approach to British labour market policy, at least in spending terms.

The real elements of innovation in the New Deal, which do not show up in expenditure data, are related to the further integration between the administrative structures for the administration of social benefits, on the one hand, and public employment and job-search services, on the other. The New Deal has consolidated a trend towards their integration that was initiated with the 1986 'Restart' programme and continued in the JSA. This ever greater emphasis on 'single administrative gateways' for the jobless in Britain contrasts with the situation in France, where co-ordination between employment and benefit administrations remains, comparatively, extremely limited. ${ }^{38}$ The initial formulations of the recent PARE project promised a greater effort in this respect, but it was precisely these proposals that were the principal victims of the search for a compromise between the social partners and the government.

Rather than an absolute opposition between an active strategy of 'workfare' and a passive strategy of 'social treatment of unemployment' in Britain and France respectively, then, it seems more accurate to speak of different forms of activation which have been privileged in each state. French policy makers have shown a marked preference for targeted, programme-based forms of activation, aimed at individuals on the fringes of the labour market and who fall outside the scope of unemployment insurance. The raft of labour market programmes specifically for the unemployed have contributed hugely to the creation of employment statutes which do no more than 'mimic' the regular employment 
contract, and as such demonstrate a thinly-veiled willingness to promote a certain 'desalarisation' of employment in France on the backs of 'problem groups' within the unemployed..$^{39}$ At the same time, though, France has moved very timidly towards more preventative, and cheaper, forms of administrative activation. In Britain, meanwhile, it is the latter that have increasingly dominated, to the progressive exclusion of the former. For example, while spending on job creation for the unemployed in the non-competitive sector represented 25\% of all British active labour market policy in 1985, by 1996 it represented no more than $2 \%$, the lowest figure in Europe apart from Luxembourg. While administration accounted for $22 \%$ of expenditure in 1985, by 1996 it represented as much as $43 \%$, far above the EU average (19\%). ${ }^{40}$

The explanation for these differences of approach to activation can be argued to lie as much in institutional legacies and their political implications as in the influence of contrasting values. In France, the principle of a closer integration between the Agence Nationale Pour l'Emploi (ANPE) and the unemployment insurance regime, the Union Nationale pour l'Emploi dans l'Industrie et le Commerce (UNEDIC), has in reality long received considerable elite support, including on parts of the political left. A 'single public employment service', integrating benefit payment, placement and training, was among the '110 propositions' on which François Mitterand was elected in 1981, and was widely seen to offer a cheap and efficient way of tackling mounting unemployment. However, the social partners, and particularly the trade unions, remain very attached to the political and organisational resources conferred on them by the autonomous mode of management, known as paritarisme, on which the UNEDIC system had been constructed in 1958. The perceived threat to this autonomy which was read into the idea of a 'single public employment service' meant that its implementation risked being very politically costly, and was quietly shelved. The same incompatibility between a doctrinaire paritarisme and a more directive administrative treatment of the unemployed is also the best explanation of the government's equivocation over the recent PARE proposal. A careful analysis of the evolution of the debate demonstrates that the Socialist government was in fact quite positive about the proposal when, in its early forms, it appeared to offer a chance for a more organic liaison between UNEDIC and the ANPE. It was only once it became clear that the PARE was not premised on an abandonment of the social partners' traditional calls for a 'clarification of responsibilities' between the state and UNEDIC that the government became more hostile. In this form, the PARE would have implied subordinating the actions of the ANPE - and a large part of the state's employment policy - to the unilateral decisions of UNEDIC. The government's eventual agreement on the PARE was largely about not wanting to be accused of being hostile to paritarisme, and the much watered-down version they accepted in this context as much about the maintenance of a fragile equilibrium between the prerogatives of UNEDIC and the ANPE as about the defence of the rights of the unemployed. ${ }^{41}$

The legacy of the historical integration of the social partners in the management of social protection in France can also help to explain the preference for expensive, programmebased measures. For another effect of the majority of the trade unions' attachment to paritarisme in core spheres of social protection has been their effective retreat from a critical engagement in developments at 'the margin' of the system. ${ }^{42}$ In this context, the development and multiplication of derogatory employment statutes for the large number of unemployed who are without insurance-based rights has generally been politically cheap for successive French governments. A similar observation could be made about the 
insertion requirement attached, in principle, to the 1988 Revenu Minimum d'Insertion (RMI) minimum-income programme, whose presentation in generous terms by policy makers was never really challenged by the union movement, who indeed were largely absent from debates over the RMI. Neither have the majority of union confederations supported the calls by associations of the unemployed themselves, and some isolated socialist MPs, for the extension of rights to a minimum income to young (under 25) people.

The state-centred administrative structure of the post-war British welfare state excluded social actors from managerial responsibilities in all the principal domains of social policy. This has been considered to have increased its vulnerability to politically and economically motivated changes because organised labour, the principal historical defenders of social rights, have neither immediate organisational interests to focus their energies, nor the possibility to enrich a social argumentation centred on the defence of social rights with a libertarian one centred on the prerogatives of 'civil society'. However, while British governments have gained from this situation in steering capacity at 'the centre' of the system, ${ }^{43}$ they have arguably paid for this in a more limited compliance at 'the margins' than seems to exist, albeit implicitly, in France.

31 This has had a significant impact on the cost of policy initiatives in the domain of unemployment. While Conservative governments in the 1980s developed large, targeted active labour market programmes in the 1980s which rivalled in expenditure terms those existing in France, they were constantly and systematically criticised by organised labour, who were quick to denounce them as 'workfare'. Economically expensive, they were thus also politically so. It was therefore in some ways logical that British governments in the late 1980s and early 1990s should turn to more administrative solutions which, if no less denounced by the unions and the opposition, had the advantage of placing considerably less of a burden on the taxpayer.

Even these relatively inexpensive forms of activation remained limited until the arrival of New Labour in 1997. The skill of Tony Blair's government has arguably been to profit from a favourable macro-economic environment and what remains of his party's 'social' reputation to further rehabilitate the legitimacy of an active approach to unemployment policy on the political left and centre, ${ }^{44}$ building on a transformation which had begun around the time of the Commission on Social Justice (CSJ) in the mid-1990s. It remains the case, however, that a more determined resurrection of intensive, programme-based measures - like the Jobs, Employment and Training (JET) programme imagined by the CSJ - will require a much greater budgetary commitment than New Labour have been prepared to accept until now, and thus a potentially expensive appeal to a British taxpayer who has become particularly averse to paying for social expenditure, 'productive' or otherwise.

\section{Conclusion}

It can be said that in the 1990s, Britain and France have both moved increasingly towards an unemployment policy based on activation, but in forms which reflect, to a great extent, different political incentive structures. The political implications of differentially institutionalised interests in social and unemployment protection have in this way driven unemployment policy in Britain and France in different, but not opposing, directions. If the model of 'two regulatory trinities' also emphasises institutional factors, its error is to underplay the multiplicity and complexity of institutional effects, and too quickly 
assimilate institutional variation to value difference. In this respect, the specific institutions of social and unemployment protection can be seen as a template for the effects of institutions in general, which are never unidirectional. This helps to explain why adjustment to a new economic environment has produced responses in Britain and France which are distinctive, but not altogether 'worlds apart' in either economic or social terms, and which cannot be contrasted in a simple (or simplistic) way.

As Britain and France are usually considered to lie at opposing ends of the value spectrum in Europe, seeing their unemployment policy choices as simply the 'cheapest' options available suggests that the European Commission's recent embrace of 'bench-marking' in the domain of unemployment and labour market policy may not, after all, be doomed to failure. Both British and French policy makers could undoubtedly benefit from building on each other's experience and developing more composite activation policy profiles. It remains to be seen, however, whether the 'open method of co-ordination' will be enough to encourage them to complement their adjustment strategies with more 'expensive' initiatives.

\section{NOTES}

1. M. LODIVICI, 'The dynamics of labour market reform in European countries', in G. ESPINGANDERSEN \& M. REGINI (eds.), Why Deregulate Labour Markets?, Oxford: OUP, 2000, p. 45.

2. M. MALO, L. TOHARIA, \& J. GAUTIÉ, 'France: the deregulation that never existed', in G. ESPINGANDERSEN \& M. REGINI, op. cit.

3. S. DEAKIN \& H. REED, 'River crossing or cold bath? Deregulation and employment in Britain in the 1980s and 1990s', in G. ESPING-ANDERSEN \& M. REGINI, op. cit.

4. OECD, Benefit Systems and Work Incentives, Paris: OECD, 1999; LODIVICI, op. cit.

5. T. ATKINSON \& J. MICKLEWRIGHT, 'Turning the screw: benefits for the unemployed 1979-1988', in A. DILNOT \& I. WALKER (eds.), The Economics of Social Security, Oxford: OUP, 1989; J. CLASEN, 'Managing the economic risk of unemployment in the UK, discussion paper', Robert Schuman Centre for Advanced Studies, European University Institute, 2001/C/12/4.

6. C. GROVER \& J. STEWART, " "Market workfare": social security, social regulation and competitiveness in the 1990', Journal of Social Policy, Vol. 28, n¹, 1999, pp. 73-96.

7. Page 138 in M. JONES, 'Full steam ahead to a workfare state? Analysing the UK Employment Department's abolition', Policy and Politics, Vol. 24, n², 1996, pp. 137-157.

8. R. HOLCMAN, Le chômage, Paris: La Documentation Française (Collection «Études de la Documentation Française »), 1997, p. 45.

9. M.-T. JOIN-LAMBERT (et. al.), Politiques sociales, Paris : Presses de la FNSP/Dalloz, 1997.

10. A. GRAHAM, 'The UK 1979-1995: myths and realities of conservative capitalism', in C. CROUCH \& W. STREECK (eds.), Political Economy of Modern Capitalism, London: Sage, 1997.

11. R. CAYROL, 'One century later: unions in French public opinion - representations, images and expectations', in H. CHAPMAN et al. (eds.), A Century of Organized Labor in France, New York: St. Martin's Press, 1998, p. 182.

12. Page 37 in W. VAN OORSCHOT, 'Who should get what, and why? On deservingness criteria and the conditionality of solidarity among the public', Policy and Politics, Vol. 28, n¹, 2000, pp. 33-48. 
13. D. KING, Actively seeking work? The politics of unemployment and welfare policy in Great Britain and the United States, Chicago: Chicago University Press, 1995.

14. D. KING, In the Name of Liberalism: Illiberal Social Policy in the United States and Great Britain, Oxford: OUP, 1999.

15. J.-C. BARBIER \& B. THERET 'Welfare-to-work or work-to-welfare? The French case', in R. VAN VOORHIS \& N. GILBERT (eds.), Activating the Unemployment: A Comparative Appraisal of WorkOriented Policies, New Brunswick: Transaction, 2001.

16. S. LEIBFRIED, 'Towards a European welfare state?' in C. JONES (ed.) New Perspectives on the Welfare State in Europe, London: Routledge, 1993.

17. EC, Employment in Europe 2001, DG for Employment and Social Affairs, Luxembourg: Official Publications of the European Communities, 2001.

18. Ibid.

19. Ibid.

20. Eurostat Yearbook 2001: The statistical Guide to Europe. Data 1989-99, Luxembourg: Official Publications of the European Communities, 2001.

21. H. GANßMANN, 'Labour market flexibility, social protection and unemployment', European Societies, Vol. 2, n³, 2000, pp. 243-269.

22. EC, op. cit., 2001.

23. Ibid.

24. 'Is job insecurity on the increase in OECD countries?', in Employment Outlook 1997, Paris: OECD.

25. This problem is not unique to indicators of labour market regulation. For example, in two recent studies of business conditions carried out by the European Commission and the Economic Intelligence Unit respectively, Britain came last out of 10 European countries in the first, despite being credited with the second best business environment in Europe (and the fourth best in the world) by the second. For details, see The Economist, November $24^{\text {th }}-30^{\text {th }} 2001$.

26. J.-P. FITOUSSI \& O. PASSET, «Réformes structurelles et politiques macroéconomiques : les enseignements des 'modèles' de pays " in Conseil d'Analyse Économique (ed.) Réduction du chômage: les réussites en Europe, Paris : La Documentation Française, 2000, p. 50.

27. DEAKIN \& REED, op. cit., p. 124.

28. S. PAUGAM, Salarié de la précarité : les nouvelles formes d'intégration professionnelle, Paris : PUF, 2000.

29. P. CONCIALDI, «Les travailleurs pauvres », Droit Social, $n^{\circ} 7 / 8,2000$, pp. 708-712.

30. IRES, Les marchés du travail en Europe, Paris : La Découverte (Collection « Repères »), 2000, p. 69.

31. Benefit Systems and Work Incentives, Paris : OECD, 1999, p. 34.

32. D. GALLIE \& S. PAUGAM 'Replacement rates in Europe', in Gallie, D. and S. Paugam (eds.), Welfare Regimes and the Experience of Unemployment in Europe, Oxford: OUP, 2000, p. 385.

33. D. GALLIE, S. PAUGAM \& S. JACOBS, 'Unemployment, poverty and social isolation: is there a vicious circle of social exclusion?', Paper presented at Euresco conference on Labour Market Change, Unemployment and Citizenship in Europe, 2001.

34. Labour Market Policies and the Public Employment Service, Prague Conference, Paris : OECD, 2001.

35. Ibid.

36. Ibid.

37. Page 18 in P. ROBINSON, 'Active labour market policies: a case of evidence-based policy making?', Oxford Review of Economic Policy, Vol. 16, n¹, 2000, pp. 13-26.

38. J. CLASEN, G. DUNCAN, T. EARDLEY, M. EVANS, P. UGHETTO, W. VAN OORSHCOT \& S. WRIGHT, "Towards "single gateways"? - A cross-national review of the changing roles of employment offices in seven countries', Zeitschrift für ausländisches und internationales Arbeits- und Sozialrecht, Vol. 15, $\mathrm{n}^{\circ} 1,2001$, pp. 43-63. 
39. J.-L. MEYER, Des contrats emplois solidarités aux emplois jeunes : regards sur l'insertion, Paris : L'Harmattan (Collection « logiques sociales »), 1999.

40. P. ROBINSON, art. cit., 2000.

41. D. CLEGG, 'Between two modernisations? The ideological evolution of the Parti Socialiste and the reform of unemployment compensation' (forthcoming).

42. D. DAMAMME, \& B. JOBERT, «Les paritarismes contre la démocratie sociale », Pouvoirs, $\mathrm{n}^{\circ} 94$ (Numéro spécial : «L'État-providence »), 2000, pp. 87-102.

43. C. CROUCH, 'Employment, industrial relations and social policy: new life in an old connection', Social Policy and Administration, Vol. 33, n4, 1999, pp. 437-457.

44. CLASEN, op. cit., 2001.

\section{ABSTRACTS}

Unemployment policies in Britain and France during the 1990s are often presented as being very different, and even 'worlds apart'. The reason is held to be the effect of contrasting social values on the evolution of labour market regulation in the two countries. However, behind the wellknown global figures on which this argument usually rests, we can identify a considerably more complex reality. The characterisation of each country's unemployment policies must also take into consideration more ambiguous variations, which appear to depend as much on the impact of inherited institutional structures as on truly antagonistic values.

Les politiques de lutte contre le chômage menées en Grande-Bretagne et en France pendant les années quatre-vingt-dix sont souvent présentées comme étant fondamentalement différentes, voire opposées. La raison invoquée est l'impact des valeurs sociales très contrastées sur l'évolution des formes de réglementation du marché du travail dans les deux pays. Or, si cette thèse repose sur des chiffres globaux bien connus, derrière ces statistiques se cache une réalité beaucoup plus complexe. Notre caractérisation des politiques respectives de lutte contre le chômage doit aussi prendre en compte des divergences plus ambiguës, qui semblent relever plus de la résistance des structures institutionnelles existantes que de valeurs vraiment antagonistes.

\section{AUTHORS}

\section{DANIEL CLEGG}

Doctoral candidate, Department of Social and Political Science, European University Institute, Florence.

\section{JOCHEN CLASEN}

Professor of Comparative Social Policy, Centre for Comparative Research in Social Welfare (CCRSW), University of Stirling. 